\title{
Myocardial Preconditioning by Intracoronary Adenosine Before Elective Percutaneous Coronary Intervention (Short Term Outcome)
}

\author{
Yasser El Sayed Bahnacy ${ }^{1{ }^{*}}$ FRCP, Ehab E Sayed E Hefny ${ }^{2}$ MD, Yasser E Sayed Mohamed ${ }^{2}$ MD \\ and Ibrahim Abdel Fattah Yacin ${ }^{2} \mathrm{MD}$
}

\author{
* Corresponding Author: \\ Yasser Bahnacy \\ yasserbahnacy@hotmail.com
}

Received for publication January 24, 2020; Accepted April 21, 2020; Published online April 21, 2020 .

Copyright 2020 The Authors published by Al-Azhar University, Faculty of Medicine, Cairo, Egypt. All rights reserved. This an openaccess article distributed under the legal terms, where it is permissible to download and share the work provided it is properly cited. The work cannot be changed in any way or used commercially.

doi: $10.21608 / \mathrm{aimj} .2020 .21527 .1100$

1 Damanhur Medical National Institute - CCU

2 Cardiology Department, Faculty of Medicine, Al-Azhar University Cairo, Egypt.

\begin{abstract}
Background: Pre- and post-conditioning by transient episodes of ischemia render the myocardium more resistant to subsequent ischemia, a phenomenon known as ischemic pre-conditioning. This effect is thought to be partly mediated by endogenous adenosine.

Aim of the work: : to investigate the efficacy and safety of intracoronary adenosine on myocardial perfusion in patients schedule for elective percutaneous coronary intervention.

Patients and methods: A prospective observational comparative study of 120 patients with coronary artery disease scheduled for elective percutaneous coronary intervention. Patients were randomly to receive intracoronary adenosine $(n=60)$ or placebo $(n=60)$, both groups were compared regarding clinical risk factors electrocardiographic, echocardiographic, cardiac troponin ,C-reactive protein, angiographic variables and major adverse cardiac events.

Results: Among clinical risk factors, smoking and obesity were significantly higher in placebo group. ECG data, echocardiographic data, Troponin data and myonecrosis were not statistically significant different between both groups before and after percutaneous coronary intervention, but high sensitive C-reactive protein was statistically significantly higher post percutaneous coronary intervention in placebo group. There was no statistically significant difference between both groups regarding percutaneous coronary intervention results, periprocedural complications and short term clinical outcome.

Conclusion: Myocardial preconditioning by intracoronary adenosine in patients schedule for elective percutaneous coronary intervention is safe but did not provide any benefit in terms of decreasing periprocedural myonecrosis or improving short term clinical outcome. The elevation of high sensitive C-reactive protein is determined by more vessels manipulation by more pre dilation, post dilatation and more number of stents.

Keywords: Myocardial Preconditioning; Adenosine; Percutaneous Coronary Intervention; $C$-reactive protein.
\end{abstract}

Disclosure: The authors have no financial interest to declare in relation to the content of this article. The Article Processing Charge was paid for by the authors.

Authorship: All authors have a substantial contribution to the article.

\section{INTRO DUCTION}

Pre- and post-conditioning by transient episodes of ischemia render the myocardium more resistant to subsequent ischemia, a phenomenon known as ischemic pre-conditioning. ${ }^{1}$ Pre-conditioning has been shown to improve outcomes in patients undergoing coronary artery bypass graft and elective percutaneous coronary intervention (PCI). ${ }^{2}$ It is very well documented that there is a release of adenosine during ischemic preconditioning, which plays a key role in inducing cardioprotection. ${ }^{3}$ The mechanism of the protective effect of adenosine remains elusive. Postulated mechanisms include hyperaemia, ${ }^{4}$, preconditioning, ${ }^{5}$ anti-platelet effect, 6 and anti-inflammatory effect. ${ }^{7}$
Coronary angioplasty currently represents the most used revascularization strategy in patients with coronary artery disease. However PCI is associated with up to $30 \%$ incidence of myonecrosis, as reflected by elevation of cardiac enzymes in an otherwise successful procedure. $^{8}$

Myonecrosis after PCI of varying extents has been shown to be associated with an increased risk of future adverse cardiac events including death and myocardial infarction. ${ }^{9}$

However, clinical studies with adenosine in humans have yielded mixed results. The aim of the our study was to investigate the benefits and safety of myocardial preconditioning by intracoronary 
adenosine on myocardial perfusion in patients schedule for elective PCI.

Our study is one of the few trials investigating the impact of adenosine bolus pretreatment on the incidence of myonecrosis in patients undergoing elective PCI as most of other studies done in setting of 1ry PCI during acute ST-elevation myocardial infarction (STEMI) with conflicting results. 10,11,12,13

\section{PATIENTS AND METHODS}

We conducted a single-center, prospective observational study that included 120 patients with established coronary artery disease by coronary angiography and scheduled for elective PCI in de novo native coronary lesions. Eligible patients were randomly allocated to receive intracoronary adenosine $(n=60)$ or placebo $(n=60)$ and all patients gave an informed consent before the procedure.

The basic demographic data and clinical cardiovascular risk factors were collected including age, sex, smoking status (including shisha), hypertension, diabetes mellitus, hyperlipidemia, obesity and family history of ischemic heart disease.

\section{Exclusion criteria:}

1- Inability to give informed consent

2- High-grade atrioventricular block, bradycardia with heart rate below 50 beats /minute.

3- Severe bronchial asthma or treatment with theophylline

4- Cardiogenic shock or left ventricular ejection fraction $(\mathrm{EF}) \leq 30 \%$

5- The occurrence of myocardial infarction one week or less before the study.

6- Previous coronary artery bypass surgery (CABG) or previous $\mathrm{PCI}$

7- Patients with chronic total occlusion of coronary arteries

8-Patients with two or multivessel disease.

All patients undergone clinical examination, ECG monitoring during the procedure with 12-lead ECG before and after PCI, Trans-thoracic echocardiography was performed before and after PCI, Laboratory investigation included cardiac enzymes by high sensitive Troponin $-\mathrm{I}$ and inflammatory marker by high sensitive $\mathrm{C}$ - reactive protein (hs-CRP) pre and 8-12 hours after PCI. All patients undergone coronary angiography by the standard Judkins technique, type of coronary lesions were assessed ${ }^{\mathbf{1 4}}$ and coronary artery stenosis greater than $70 \%$ in multiple angiographic views was defined as severe disease. ${ }^{15} \mathrm{PCI}$ done according to coronary angiography findings and the use of balloons for pre dilatation or post dilatation, stent type and the use of glycoprotein II b/III a inhibitors, all were left to the discretion of the individual operator.

Patients randomized to the adenosine group were given 50 microgram adenosine ${ }^{\mathbf{1 6}}$, (diluted into $5 \mathrm{ml}$ normal saline) through the guiding catheter into the target coronary artery prior to guidewire advancement and for more than one lesion in same vessel another 50 microgram of adenosine were given prior to intervention of the second lesion, while those randomized to the placebo were given 5 $\mathrm{ml}$ normal saline.

Endpoints were chest pain, ST - T segment changes on the ECG during and after PCI, TIMI flow grade $^{17}$, periprocedure complications e.g. angiographic slow/no-reflow after PCI or distal embolization defined as a filling defect distal to the culprit lesion on the angiogram at any time point after the first balloon inflation ${ }^{18}$ and high sensitive Troponin - I and hs-CRP rise post PCI. Myonecrosis/Myocardial Infarction defined as an increase (peak value) in troponin $-\mathrm{I} \geq 5$ times the upper limit of normal (ULN). ${ }^{19}$

All patients underwent follow up for at least 3 months for overall major adverse cardiac events (MACE) as death, need for target lesion revascularization (TLR), recurrent Myocardial Infarction (MI), heart failure (HF) and cerebrovascular event (CVE).

\section{STATISTICAL ANALYSIS}

Both groups were compared regarding clinical risk factors, electrocardiographic, echocardiographic, cardiac troponin, CRP, angiographic variables, PCI dat a and MACE .

All statistical analyses were generated based on intention-to-treat and data were fed to the computer and analyzed using IBM SPSS software package version 20.0. (Armonk, NY: IBM Corp) Qualitative data were described using number and percent. Significance of the obtained results was judged at the 5\% level. All $\mathrm{P}$ values were two-sided and $\mathrm{P}<$ 0.05 was considered statistically significant. The used tests were :

1- Chi-square test : for categorical variables, to compare between different groups

2- Fisher's Exact or Monte Carlo correction: for chi-square when more than $20 \%$ of the cells have expected count less than 5

3- Student t-test : for normally distributed quantitative variables, to compare between two studied groups.

\section{RESULTS}

\section{Baseline clinical Characteristics}

The study population included (120) patients scheduled for elective PCI, age range between 32 and 88 years, with a mean age of 56 years and the majority were males (143 comprise $67 \%$ of the study population).

As regard clinical risk factors in all the study population, 62 patients $(51.7 \%)$ were smokers, 23 patients $(26.7 \%)$ had diabetes mellitus (DM), 64 patients $(53.3 \%)$ had hypertension (HTN), 26 
patients $(21.7 \%)$ had dyslipidemia, 11 patients $(9.1 \%)$ had family history of ischemic artery disease and 59 patients $(49.2 \%)$ were obese. Table (1) shows that there was no statistically significant difference between both groups except smoking and

\begin{tabular}{|c|c|c|c|c|c|c|c|c|}
\hline \multirow{2}{*}{ Risk Factors } & \multicolumn{2}{|c|}{$\begin{array}{c}\text { Total } \\
(\mathbf{n}=\mathbf{1 2 0})\end{array}$} & \multicolumn{2}{|c|}{$\begin{array}{l}\text { Adenosine } \\
(\mathrm{n}=60)\end{array}$} & \multicolumn{2}{|c|}{$\begin{array}{c}\text { Place bo } \\
(n=60)\end{array}$} & \multirow{2}{*}{$\chi^{2}$} & \multirow{2}{*}{$\mathbf{p}$} \\
\hline & No. & $\%$ & No. & $\%$ & No. & $\%$ & & \\
\hline Male sex & 81 & 67.5 & 39 & 65.0 & 42 & 70.0 & $\begin{array}{c}\chi^{2}= \\
0.342\end{array}$ & 0.697 \\
\hline Mean \pm SD. & $\begin{array}{r}56.01 \pm \\
8.86 \\
\end{array}$ & $\begin{array}{r}55.77 \pm \\
9.39 \\
\end{array}$ & $\begin{array}{r}56.25 \pm \\
8.36 \\
\end{array}$ & $\begin{array}{r}\text { Mean } \pm \\
\text { SD. }\end{array}$ & $\begin{array}{r}56.01 \pm \\
8.86 \\
\end{array}$ & $\begin{array}{r}55.77 \pm \\
9.39 \\
\end{array}$ & $\mathrm{t}=0.298$ & 0.766 \\
\hline DM & 32 & 26.7 & 18 & 30.0 & 14 & 23.3 & 0.682 & 0.409 \\
\hline HTN & 64 & 53.3 & 33 & 55.0 & 31 & 51.7 & 0.134 & 0.714 \\
\hline Dyslipidemia & 26 & 21.7 & 9 & 15.0 & 17 & 28.3 & 3.142 & 0.076 \\
\hline Smoking & 62 & 51.7 & 23 & 38.3 & 39 & 65.0 & $8.543^{*}$ & $0.003^{*}$ \\
\hline Obesity & 59 & 49.2 & 24 & 40.0 & 35 & 58.3 & $4.034^{*}$ & $0.045^{*}$ \\
\hline $\begin{array}{r}\text { Family history of } \\
\text { IHD }\end{array}$ & 1 & 0.8 & 0 & 0.0 & 1 & 1.7 & 1.008 & ${ }^{\mathrm{FE}} \mathrm{p}=1.000$ \\
\hline
\end{tabular}

$\chi^{2}$ : Chi square test FE: Fisher Exact $t$ : Student t-test

$\mathbf{P}$ :p value for comparing between the two studied groups

Table 1: Demographic and clinical characteristics of study population

\section{Baseline Diagnosis}

The majority of baseline diagnosis among the study population was previous STEMI in about $50 \%$ of cases followed by previous non ST-elevation myocardial infarction (NSTEMI) in $35 \%$, unstable angina in $11 \%$ and only 3 cases were stable angina with no statistically significant difference between both groups.

\section{ECG data}

Regarding baseline ECG changes, before PCI there was statistically significant difference between both groups, as more normal ECG and less ST - T changes were found in adenosine group compared to placebo obesity as both were significantly higher in placebo group with significant $(\mathrm{P}$ value $<0.05$ ).

\begin{tabular}{|c|c|c|c|c|c|c|}
\hline \multirow[t]{2}{*}{ High sensitive Troponin I } & \multicolumn{2}{|c|}{$\begin{array}{l}\text { Adenosine } \\
\quad(n=60)\end{array}$} & \multicolumn{2}{|c|}{$\begin{array}{c}\text { Placebo } \\
(n=60)\end{array}$} & \multirow[t]{2}{*}{$\chi^{2}$} & \multirow[t]{2}{*}{$\mathbf{p}$} \\
\hline & No. & $\%$ & No. & $\%$ & & \\
\hline $\begin{array}{c}\text { Before PCI } \\
\text { Normal } \\
\text { Increased }\end{array}$ & $\begin{array}{c}60 \\
0\end{array}$ & $\begin{array}{c}100.0 \\
0.0\end{array}$ & $\begin{array}{c}60 \\
0\end{array}$ & $\begin{array}{c}100.0 \\
0.0\end{array}$ & - & - \\
\hline $\begin{array}{c}\text { After PCI } \\
\text { Normal } \\
\text { Increased }\end{array}$ & $\begin{array}{l}39 \\
21\end{array}$ & $\begin{array}{l}65.0 \\
35.0\end{array}$ & $\begin{array}{l}38 \\
22\end{array}$ & $\begin{array}{l}63.3 \\
36.7\end{array}$ & 0.036 & 0.849 \\
\hline
\end{tabular}

x2: Chi square test hs-CRP :high sensitive C-reactive protein p: $p$ value for comparing between the two studied groups

Table 2: Comparison between the two studied groups according to High sensitive Troponin I 


\begin{tabular}{|c|c|c|c|c|c|c|}
\hline \multirow{2}{*}{ hs-CRP } & \multicolumn{2}{|c|}{$\begin{array}{c}\text { Adenosine } \\
(\mathrm{n}=60)\end{array}$} & \multicolumn{2}{|c|}{$\begin{array}{r}\text { Place bo } \\
(n=60)\end{array}$} & \multirow{2}{*}{$\chi^{2}$} & \multirow{2}{*}{$\mathbf{p}$} \\
\hline & No. & $\%$ & No. & $\%$ & & \\
\hline $\begin{array}{c}\text { Before PCI } \\
\text { Normal } \\
\text { Increased }\end{array}$ & $\begin{array}{c}59 \\
1 \\
\end{array}$ & $\begin{array}{c}98.3 \\
1.7\end{array}$ & $\begin{array}{c}60 \\
0\end{array}$ & $\begin{array}{c}100.0 \\
0.0\end{array}$ & 1.008 & $\begin{array}{l}{ }^{\mathrm{rE}} \mathrm{p}= \\
1.000\end{array}$ \\
\hline $\begin{array}{c}\text { After PCI } \\
\text { Normal } \\
\text { Increased }\end{array}$ & $\begin{array}{c}59 \\
1\end{array}$ & $\begin{array}{c}98.3 \\
1.7\end{array}$ & $\begin{array}{l}49 \\
11\end{array}$ & $\begin{array}{l}81.7 \\
18.3\end{array}$ & $9.259^{*}$ & $0.002^{*}$ \\
\hline
\end{tabular}

x2: Chi square test hs-CRP :high sensitive C-reactive protein

p: $p$ value for comparing between the two studied groups $\mathbf{F E}$ : Fisher Exact *: Statistically significant at $\mathrm{p} \leq 0.05$

Table 3: Comparison between the two studied groups according to hs-CRP

\section{Echocardiographic data}

In the adenosine group there was statistically significant more cases with normal ejection fraction (EF \%) compared with placebo group with (P value $<0.05$ ). While patient with baseline mild LV systolic dysfunction were statistically significantly higher in placebo group compared with adenosine group with ( $\mathrm{P}$ value $<0.05$ ). Other parameters including left ventricular dimensions, left atrial dimensions and regional wall motion abnormalities before $\mathrm{PCI}$ and after PCI were not of statistical significant difference between both groups.

\section{Angiographic data}

In adenosine group the culprit artery was LAD in 65 $\%$, RCA in $18 \%$ and LCX in $8 \%$ of cases, while in placebo group LAD was in $75 \%$, RCA in $13 \%$ and LCX in $8 \%$ of cases with no statistical significant difference between both groups and the culprit artery among all population groups was LAD in about $70 \%$ of cases.

\section{PCI data}

There was statistically significant difference between patients in adenosine and patients in placebo group regarding type of lesion, with more type A lesions and less type B lesions in adenosine than in placebo group, also two stents implantation was statistically significantly higher in placebo group compared with adenosine group with significant $\mathrm{P}$ value $(<0.05)$, (Figure 1) but there was no statistically significant difference between both groups regarding other PCI data including predilatation, post dilatation and types of stents which were drug eluting stents (DES) in all patients except one bare metal stent (BMS) as available size in adenosine group. (Table 4)

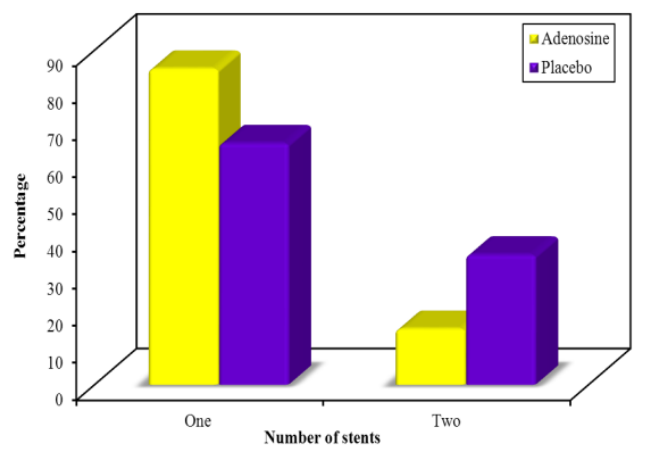

Fig. 1: Comparison between the two studied groups according to Number of stents

\begin{tabular}{|c|c|c|c|c|c|c|}
\hline \multirow[t]{2}{*}{ PCI data } & \multicolumn{2}{|c|}{$\begin{array}{c}\text { Adenosine } \\
(\mathrm{n}=60)\end{array}$} & \multicolumn{2}{|c|}{$\begin{array}{l}\text { Placebo } \\
(n=60)\end{array}$} & \multirow[t]{2}{*}{$\chi^{2}$} & \multirow[t]{2}{*}{$\mathbf{p}$} \\
\hline & No. & $\%$ & No. & $\%$ & & \\
\hline Type A lesion & 51 & 85.0 & 39 & 65.0 & 6400 & 0.011 \\
\hline Type B lesion & 9 & 15.0 & 21 & 35.0 & 0.400 & 0.011 \\
\hline $\begin{array}{l}\text { Pre-dilatation } \\
\text { No } \\
\text { Yes } \\
\end{array}$ & $\begin{array}{l}40 \\
20 \\
\end{array}$ & $\begin{array}{l}66.7 \\
33.3 \\
\end{array}$ & $\begin{array}{l}42 \\
18 \\
\end{array}$ & $\begin{array}{l}70.0 \\
30.0\end{array}$ & 0.154 & 0.695 \\
\hline $\begin{array}{l}\text { Post-dilatation } \\
\text { No } \\
\text { Yes }\end{array}$ & $\begin{array}{l}41 \\
19\end{array}$ & $\begin{array}{l}68.3 \\
31.7\end{array}$ & $\begin{array}{l}43 \\
17\end{array}$ & $\begin{array}{l}71.7 \\
28.3\end{array}$ & 0.159 & 0.690 \\
\hline $\begin{array}{l}\text { Number of stents } \\
\text { One } \\
\text { Two }\end{array}$ & $\begin{array}{c}51 \\
9\end{array}$ & $\begin{array}{l}85.0 \\
15.0\end{array}$ & $\begin{array}{l}39 \\
21\end{array}$ & $\begin{array}{l}65.0 \\
35.0\end{array}$ & $6.400^{*}$ & $0.011^{*}$ \\
\hline $\begin{array}{c}\text { Type of stent } \\
\text { DES } \\
\text { BMS }\end{array}$ & $\begin{array}{c}59 \\
1\end{array}$ & $\begin{array}{c}98.3 \\
1.7\end{array}$ & 60 & $\begin{array}{c}100.0 \\
0.0\end{array}$ & 1.008 & $\begin{array}{l}\mathrm{FE}_{\mathrm{p}}= \\
1.000\end{array}$ \\
\hline
\end{tabular}

Table 4: Comparison between the two studied groups according to PCI data 


\section{PCI results and complications}

There was no statistically significant difference between both groups regarding PCI data as chest pain, TIMI flow and periprocedural complications as slow flow, no reflow or distal embolization. After adenosine administration, there was no incidence of significant bradycardia, pauses, hypotension, ventricular arrhythmias or heart block and all the procedures were successful and uncomplicated.

Relation betwe en increase hs-CRP after PCI and data of place bo group

In sub analysis of patients in placebo group with increased hs-CRP after PCI, there was no statistical significant relationship between rise of hs-CRP and patients risk factors, basal diagnosis, ECG data, Echo data , but there was significant statistical relationship between rise of hs-CRP and increased number of diseased vessels, more type B-lesion in those patients and by more manipulation of diseased vessel througn pre dilatation, post dilatation and by increasing number of implanted stents (Table 5)

Clinical outcome (MACE) data

Short term follow up during both in-hospital period and for at least three months after PCI for clinical outcome, there was no statistically significant difference between both groups regarding MACE including death, MI, TVR, HF, CVE. (Table 6)

\begin{tabular}{|c|c|c|c|c|c|c|}
\hline \multirow{3}{*}{ PCI data } & \multicolumn{4}{|c|}{ hs-CRP after PCI } & \multirow{3}{*}{$\chi^{2}$} & \multirow{3}{*}{${ }^{\mathrm{FE}} \mathbf{p}$} \\
\hline & \multicolumn{2}{|c|}{$\begin{array}{l}\text { Normal } \\
(n=49)\end{array}$} & \multicolumn{2}{|c|}{$\begin{array}{c}\text { Increased } \\
(n=11)\end{array}$} & & \\
\hline & No. & $\%$ & No. & $\%$ & & \\
\hline $\begin{array}{c}\text { Type of lesion } \\
\text { A } \\
\text { B }\end{array}$ & $\begin{array}{l}38 \\
11\end{array}$ & $\begin{array}{l}77.6 \\
22.4\end{array}$ & $\begin{array}{c}1 \\
10\end{array}$ & $\begin{array}{l}36.4 \\
63.6\end{array}$ & $18.507^{*}$ & $<0.001^{*}$ \\
\hline $\begin{array}{l}\text { Pre dilatation } \\
\text { No } \\
\text { Yes } \\
\end{array}$ & $\begin{array}{l}38 \\
11 \\
\end{array}$ & $\begin{array}{l}77.6 \\
22.4 \\
\end{array}$ & $\begin{array}{l}4 \\
7 \\
\end{array}$ & $\begin{array}{l}36.4 \\
63.6 \\
\end{array}$ & $7.257^{\circ}$ & $0.012^{\circ}$ \\
\hline $\begin{array}{l}\text { Post-dilatation } \\
\text { No } \\
\text { Yes }\end{array}$ & $\begin{array}{l}39 \\
10\end{array}$ & $\begin{array}{l}79.6 \\
20.4\end{array}$ & $\begin{array}{l}4 \\
7\end{array}$ & $\begin{array}{l}36.4 \\
63.6\end{array}$ & $8.267^{*}$ & $0.008^{*}$ \\
\hline $\begin{array}{l}\text { Number of stents } \\
\text { One } \\
\text { Two }\end{array}$ & $\begin{array}{l}38 \\
11\end{array}$ & $\begin{array}{l}77.6 \\
22.4\end{array}$ & $\begin{array}{c}1 \\
10\end{array}$ & $\begin{array}{c}9.1 \\
90.9\end{array}$ & $18.507^{*}$ & $<0.001^{*}$ \\
\hline $\begin{array}{l}\text { Type of stent } \\
\text { DES } \\
\text { BMS }\end{array}$ & $\begin{array}{c}49 \\
0\end{array}$ & $\begin{array}{c}100.0 \\
0.0\end{array}$ & $\begin{array}{c}11 \\
0\end{array}$ & $\begin{array}{c}100.0 \\
0.0\end{array}$ & - & - \\
\hline
\end{tabular}

$$
\chi^{2} \text { : Chi square test } \quad \text { FE: Fisher Exact }
$$

p: $\mathrm{p}$ value for association between during/after PCI and ECHO *: Statistically significant at $\mathrm{p} \leq 0.05$

Table 5: Relation between increase hs-CRP after PCI and PCI data of placebo group $(n=60)$

\begin{tabular}{||c|c|c|c|c|c|c||}
\hline \multirow{2}{*}{ Clinical outcome (MACE) } & \multicolumn{2}{|c|}{$\begin{array}{c}\text { Adenosine } \\
(\mathbf{n = 6 0 )}\end{array}$} & \multicolumn{2}{c|}{$\begin{array}{c}\text { Placebo } \\
(\mathbf{n = 6 0}\end{array}$} & \multirow{2}{*}{$\chi^{2}$} & \multirow{2}{*}{${ }^{\mathbf{F E}_{\mathbf{p}}}$} \\
\cline { 2 - 6 } & $\mathbf{N o}$ & $\mathbf{\%}$ & $\mathbf{N o}$ & $\mathbf{\%}$ & & \\
\hline Death & 0 & 0.0 & 1 & 1.7 & 1.008 & 1.000 \\
MI & 0 & 0.0 & 0 & 0.0 & - & - \\
TVR & 1 & 1.7 & 0 & 0.0 & 1.008 & 1.000 \\
HF & 0 & 0.0 & 2 & 3.3 & 2.034 & 0.496 \\
CVE & 0 & 0.0 & 0 & 0.0 & - & - \\
\hline
\end{tabular}

$\mathbf{x}^{2}$ : Chi square test

FE: Fisher Exact

p: $p$ value for comparing between the two studied groups

Table 6: Comparison between the two studied groups according to Clinical outcome (MACE)

\section{DISC USSION}

Ischemic preconditioning is a powerful tool in which brief episodes of ischemia and reperfusion protect the heart from subsequent prolonged ischemia. ${ }^{1}$ Pre-conditioning has been shown to improve outcomes in patients undergoing coronary artery bypass graft and elective PCI. ${ }^{2}$ It is very well documented that there is a release of adenosine during ischemic preconditioning, which plays a key role in inducing cardioprotection. ${ }^{3}$

Percutaneous coronary intervention (PCI) is associated with up to $30 \%$ incidence of myonecrosis, as reflected by elevation of cardiac 
enzymes in an otherwise successful procedure. ${ }^{20}$ Apart from side-branch occlusion, intimal dissection and coronary spasm, a possible aetiology of myonecrosis after PCI might be distal embolization of atherogenic materials from plaque disruption, causing obstruction of blood flow at capillary level resulting in micro-infarction. ${ }^{\mathbf{2 1 , 2 2}}$ Using late gadolinium enhancement cardiac MRI before and shortly after PCI or CABG, found that $32 \%$ of patients had evidence of procedural myocardial injury. ${ }^{23}$

One animal study suggested endogenous release of adenosine could compensate for the distal embolization of small particles with adenosine pretreatment before guidewire advancement, they believe the hyperaemic effect might be sufficient to ameliorate distal embolization of relatively small platelet thrombi following elective PCI. ${ }^{24}$

Our study is one of the few trials investigating the impact of adenosine bolus pretreatment on the incidence of myonecrosis in patients undergoing elective PCI as most of other studies were done in setting of 1ry PCI during acute STEMI with conflicting results. Trials demonstrated that adenosine reduced infarct size, but did not reduce the primary clinical endpoint AMIST AD-I ${ }^{\mathbf{1 0}}$ and AMIST AD-II ${ }^{11}$, while other trials demonstrated that intracoronary adenosine did not attenuate infarct size and microvascular obstruction using Tc-99 m sestamibi single-photon emission computed tomography (SPECT). ${ }^{\mathbf{1 2 , 1 3}}$

In our study, the mean age of patients was 56 years, and $67 \%$ were males, $51.7 \%$ were smokers, $26.7 \%$ had diabetes mellitus, 53.3\% had hypertension, $21.7 \%$ had hyperlipidemia, and $49.2 \%$ were obese. Among these risk factors only smoking and obesity were higher in placebo

group with statistically significant difference.

Regarding ECG data, ECHO data and baseline diagnosis, there was no significant difference between both groups. Although no difference was observed in terms of troponin release and periprocedural myonecrosis or MI, there was a significant difference for increased hs-CRP in placebo group after PCI. In our study no significant statistical difference in studied groups as regards short term clinical outcome despite one patients died, and two patients had heart failure in placebo group while one patient had target vessel revascularization in adenosine group. Intracoronary administration of adenosine in our study was safe with no major adverse effects were observed.

In agreement with our results, stable patients in the PREVENT-ICARUS trial undergoing elective PCI, intracoronary adenosine was not associated with a reduction of periprocedural myocardial infarction, Thrombolysis In Myocardial Infarction flow, or inhospital death. ${ }^{25}$

Similar findings have been observed in in RACE trial, presented at the Euro-PCR 2010, including 160 patients undergoing elective $\mathrm{PCI}$ in which patient were randomized to pretreatment with clopidogrel or treatment with intracoronary adenosine $(50 \mathrm{mic})$ before crossing with the wire, followed by an additional $(50 \mathrm{mic})$ before initial balloon predilatation or stenting. Although no statistical significant difference was observed in terms of troponin release, adenosine was associated with a relevant reduction in periprocedural MI, defined as CK-MB release $>3$ times the ULN. ${ }^{26}$

Contradicting to our study, Mohamed Shehata et al. in their study which included 100 diabetic patients with chronic stable angina were randomly assigned to undergo elective PCI with intracoronary adenosine;100 $\mu \mathrm{g} /$ stented vessel, (group-A, 50 patients) or standard PCI (group-B, 50 patients). Their conclusion that in diabetic patients undergoing elective PCI, intracoronary adenosine was associated with decreased incidence of PCIrelated myocardial injury and improvement of left ventricular EF \% after 3 months despite there was no statistically significant difference between both groups regarding incidence of major adverse cardiac events (MACE). ${ }^{27}$

Against our study, Chi-hang Lee et al. In their study of 62 patients undergoing elective coronary angioplasty showed that pretreatment with intracoronary adenosine prevents the risk of periprocedural myocardial infarction. ${ }^{\mathbf{2 8}}$

In our current study the expected occurrence of periprocedural myonecrosis was absent, this may be potentially resulted from the low risk profile of our patients being not in acute coronary syndrome (ACS) sitting, our patients were patients with single vessel disease and not for complex PCI (e.g. multivessel disease PCI, chronic total occlusion, thrombus-containing lesions, bifurcation, saphenous graft).

In our study there was no statistically significant difference between both groups regarding baseline hs-CRP before PCI but there was statistically significant increase after PCI in placebo group with significant ( $\mathrm{P}$ value $<0.05)$.

High sensitivity C-reactive protein (hs-CRP) is one of the most extensively investigated markers of inflammation and has been used to predict the risk of major adverse cardiac events in patients with stable and unstable coronary artery disease after PCI. ${ }^{29}$

Despite inflammation has a central role in the pathogenesis of atherosclerosis as well as plaque instability, neither the meta-analyses nor the JUPITER trial were able to answer the question if CRP is a causal factor in coronary heart disease or just an innocent bystander in inflammation, a wellaccepted pathomechanism in atherosclerosis. ${ }^{30}$ Importantly, PCI itself causes an acute vascular and systemic inflammatory response, which is diminished by potent preprocedural antiplatelet (glycoproרtein IIb/IIIa inhibitors, clopidogrel, and other P2Y12 inhibitors) and statin therapy. ${ }^{\mathbf{3 1}}$ Prior studies exploring the relationship between hs-CRP and periprocedural MI have yielded conflicting results. ${ }^{32}$ 
A prospective study by Joerg Herrmann et al among 513 patients undergoing elective PCI and examined the relationship between pre and postprocedural hsCRP levels and outcomes found that there was no relationship between hs-CRP and mortality and a weak univariate relationship with the combined end point of death or MI. ${ }^{33}$

Almagor $\mathrm{M}$ et al. measured serum CRP levels in 40 patients. Group 1 consisted of 12 consecutive patients with stable coronary artery disease (CAD)who were at low risk, before and after elective coronary stent implantation. They compared the results in these patients to those of patients in 2 control groups: group 2 consisted of 12 consecutive patients with non-STE-ACS who were undergoing coronary stent implantation, and group 3 included 16 consecutive patients with stable or unstable CAD who were undergoing diagnostic coronary angiography only without PCI. They concluded that mechanical disruption of an atherosclerotic coronary plaque during elective coronary stent implantation in patients with stable CAD who are at low risk causes a systemic inflammatory response expressed by marked elevation in CRP concentration. ${ }^{31}$

Similar results by Ahmed Bendary et al. They measured hs- CRP in 60 patients divided into three groups: Group I (20 patients with stable CAD undergoing elective PCI), Group II (20 patients with non STE-ACS undergoing PCI), and Group III (20 patients with stable and unstable CAD undergoing angiography without $\mathrm{PCI}$ ), their conclusion was that iatrogenic disruption of plaques by $\mathrm{PCI}$ in stable CAD resulted in a significant rise of hs CRP. However, this does not impact the short term outcome. ${ }^{34}$

In our study and in sub analysis of patients in placebo group with increase hs-CRP after PCI, trying to find any correlation between patients data and rise of hs-CRP, there was no statistical significant relationship between rise of hs-CRP and patients risk factors, basal diagnosis, ECG data, Echo data, but there was significant statistical relationship between rise of hs-CRP and the more diseased vessels by more type B-lesion in those patients and by more manipulation of diseased vessel by pre dilatation, post dilatation and by more number of stents implanted, with significant Pvalue, despite not affecting our study clinical outcome. All of these factors may cause more disruption of atherosclerotic plaque which could induce more inflammatory response explaining increased hs-CRP.

\section{STUDY LIMITATIO NS}

Our study had a number of limitations, first being a single center study and relatively small number of patients. Second we did not consider the option of double blind study as it was almost impossible to blind the operators, as patients would develop transient heart block and bradycardia after adenosine administration so the operators have to pay close attention to monitor during the adenosine administration. A third limitation is that our patients were patients with only single vessel disease thus the results of our study may not be applicable to patients with multivessel disease. A fourth limitation is that we did not use other imaging modalities like myoview or cardiac magnetic imaging for detection of periprocedural myocardial infarction.

\section{CONCLUSION}

Myocardial preconditioning by intracoronary bolus of adenosine in patients schedule for elective percutaneous coronary intervention is safe but does not provide any benefit in terms of preventing periprocedural myonecrosis or MI and did not affect short term clinical outcome.

The inflammatory response to percutaneous coronary intervention by high sensitive C-reactive protien is determined by more manipulation of already more diseased vessels that required more pre dilation, post dilatation and more number of stents and is not secondary to periprocedural myocardial injury and not affect short term clinical outcome. Further studies with a larger sample size are needed to provide more supporting results to our study.

\section{AC KNO W LEDGMENTS}

Thanks for all our patients who share in this study, to catheterization laboratory nurses and technicians and for my professors of cardiology from faulty of medicine -Al- azhar university

\section{REFER ENCES}

1. Murry CE, Jennings RB and Reimer KA. Preconditioning with ischemia: a delay of lethal cell injury in ischemic myocardium. Circulation, 1986;74:1124-36.

2. Yellon DM, Alkhulaifi AM and Pugsley WB. (1993) Preconditioning the human myocardium. Lancet, 1993; 342:276-7.

3. Cohen MV, Baines $\mathrm{CP}$ and Downey JM. Ischemic preconditioning from adenosine receptor to KATP channel. Annu Rev Physiol. 2000; 62:79-109.W

4. ilson RF, Wyche $\mathrm{K}$, Christensen BV,et al. Effects of adenosine on human coronary arterial circulation. Circulation, 1990; 82:1595-1606.

5. Leesar MA, Stoddard M, Ahmed M, et al. Preconditioning of human myocardium with adenosine during coronary angioplasty. Circulation, 1997; 95:2500-2507. 
6. Hata K, Whittaker P, Kloner RA, et al. Brief antecedent ischemia attenuates platelet-mediated thrombosis in damaged and stenotic canine coronary arteries: role of adenosine. Circulation, 1998; 97:692-702.

7. Headrick JP, Hack B and Ashton KJ. Acute adenosinergic cardioprotection in ischemicreperfused hearts. Am J Physiol Heart Circ Physiol. 2003; 285:H1797-818 .

8. Califf RM, Abdelmeguid AE, Kuntz RE, et al. Myonecrosis after revascularization procedures. J Am Coll Cardiol. 1998; 31:241-251.

9. Cavallini C, Savonitto S, Violini $\mathrm{R}$, et al. Atherosclerosis 'Thrombosis, Vascular Biology', 'Society for Invasive CardiologyGISE 'Investigators. Impact of the elevation of biochemical markers of myocardial damage on long-term mortality after percut aneous coronary intervention: results of the CK-MB and PCI study. Eur Heart J, 2005 26:1494-1498 .

10. Mahaffey KW, Puma JA, Barbagelata NA, et al. Adenosine as an adjunct to thrombolytic therapy for acute myocardial infarction: results of a multicenter 'randomized, placebo-controlled trial: the Acute Myocardial Infarction ST udy of ADenosine (AMIST AD) trial. $J$ Am Coll Cardiol. 1999; 34:1711-20 .

11. Ross AM, Gibbons RJ, Stone GW, et al. A randomized 'double-blinded, placebo-controlled multicenter trial of adenosine as an adjunct to reperfusion in the treatment of acute myocardial infarction (AMIST AD-II). $J$ Am Coll Cardiol. 2005; 45: 1775-80.

12. Fokkema ML, Vlaar PJ, Vogelzang M, et al. Effect of high-dose intracoronary adenosine administration during primary percutaneous coronary intervention in acute myocardial infarction: a randomized controlled trial. Circ Cardiovasc Interv, 2009; 2:323-9.

13. Sheraz AN, Jamal NK, Islam ZM, et al. The REFLO-STEMI trial comparing intracoronary adenosine, sodium nitroprusside and standard therapy for the attenuation of infarct size and microvascular obstruction during primary percutaneous coronary intervention. Trials, $2014 ; 15: 371$

14. Ryan TJ, Faxon DP, Gunnar RM, et al. Guidelines for percutaneous transluminal coronary angioplasty. A report of the American College of Cardiology/American Heart Association Task Force on Assessment of Diagnostic and Therapeutic Cardiovascular Procedures (Subcommittee on Percutaneous
Transluminal Coronary Angioplasty). Circulation. 1988; 78:486-502.

15. Stephan Windecker, Philippe Kolh, Fernando Alfonso et al. ESC/EACTS Guidelines on myocardial revascularization. European Heart Journal, 2014 ؛35:2541-2619.

16. Levine GN, Bates ER, Blankenship JC, et al. American College of Cardiology Foundation; American Heart Association Task Force on Practice Guidelines ؛ Society for Cardiovascular Angiography and Interventions. 2011 ACCF/AHA/SCAI Guideline for Percutaneous Coronary Intervention: a report of the American College of Cardiology Foundation/American Heart Association. J Am Coll Cardiol, 2011; 58:e44-122.

17. The TIMI study group. The Thrombolysis in Myocardial Infarction (TIMI) trial phase I findings. $N$ Engl J Med, 1985; 312:932-936.

18. Ishizaka N, Issiki T, Saeki F, et al. Predictors of myocardial infarction after distal embolization of coronary vessels with percutaneous transluminal coronary angioplasty. Experience of 21 consecutive patients with distal embolization. Cardiology, 1994; 84: 298-303.

19. Jaffe, A. S., B. R. Chaitman, D. A. Morrow, et al. "Fourth universal definition of myocardial infarction (2018)." European Heart Journal 2018; 40 (3): 237-269.

20. Califf RM, Abdelmeguid AE, Kuntz RE et al. Myonecrosis after revascularization procedures. J Am Coll Cardiol, 1998; 31: 241-251.

21. Mehran R, Dangas G, Mintz GS, et al. Atherosclerotic plaque burden and CK-MB enzyme elevation after coronary interventions : intravascular ultrasound study of 2256 patients. Circulation, 2000; 101:604-610.

22. Choi JW, Gibson CM, Murphy SA, et al. Myonecrosis following stent placement: association between impaired TIMI myocardial perfusion grade and MRI visualization of microinfarction. Catheter Cardiovasc Interv, 2004; 61:472-476.

23. Rahimi K, Banning AP, Cheng AS, et al. Prognostic value of coronary revascularisationrelated myocardial injury: a cardiac magnetic resonance imaging study. Heart. 2009;95:19371943.

24. Hori M, Inoue M, Kitakaze M, et al. Role of adenosine in hyperemic response of coronary blood flow in microembolization. Am J Physiol. 1986; 250: H509-H518 . 
25. De Luca G, Iorio S, Venegoni L, et al. Evaluation of intracoronary adenosine to prevent periprocedural myonecrosis in elective percutaneous coronary intervention (from the PREVENT-ICARUS Trial). Am J Cardiol. 2012; 109:202-7.

26. Sardella G. Randomized comparison of adenosine intracoronary infusion and clopidogrel pretreatment on myonecrosis occurrence in elective PCI (RACE trial) Available at: http://www.clinicaltrialresults. org/home.htm.

27. Shehata M. Cardioprotective effects of intracoronary adenosine in diabetic patients undergoing elective percutaneous coronary intervention. Minerva Cardioangiol. 2014; 62:461-471.

28. Chi-Hang Lee, Adrian Low, Bee-Choo Tai, et al. Pretreatment with intracoronary adenosine reduces the incidence of myonecrosis after nonurgent percutaneous coronary intervention. European Heart Journal , 2007; 28, 19-25.

29. Lindahl B, Toss H, Siegbahn A, et al. Markers of myocardial damage and inflammation in relation to long-term mortality in unstable coronary artery disease. FRISC Study Group. Fragmin during Instability in Coronary Artery Disease. N Engl J Med. 2003; 343:1139-1147 .

30. Libby P, Ridker P.M and Hansson G.K. "Inflammation in Atherosclerosis: from Pathophysiology to Practice," Journal of the American College of Cardiology, 2009; 54:2129-2138.

31. Almagor M, Keren A and Banai S. Increased Creactive protein level after coronary stent implantation in patients with stable coronary artery disease. A Heart J. 2003; 145:248-253.

32. Delhaye C, Maluenda G, Wakabayashi K, et al. Long-term prognostic value of preprocedural Creactive protein after drug-eluting stent implantation. Am J Cardiol. 2010;105:826-832

33. Herrmann J, Lennon RJ, Barsness GW, et al. High Sensitivity C-Reactive Protein and Outcomes Following Percutaneous Coronary Intervention in Contemporary Practice (Circ Cardiovasc Interv). 2012; 5:783-790.

34. Ahmed Bendary, Bassel Wagdy, Tarek Aboul Azm1, et al. Elevated High-Sensitivity CReactive Protein after Percutaneous Coronary Intervention in Patients with Stable Coronary Artery Disease: A Proof-of-Concept Study. Cardiovascular Medicine. 2018; 7:130-136. 